\title{
Tools to Support Classroom Settings: Perceptions of EFL Students on ICT Usage during Pre-Service Teaching Program
}

\author{
Siti Munawaroh and Syahdan Syahdan \\ Universitas Lancang Kuning. Pekanbaru. Indonesia \\ sitimunawaroh6890@gmail.com
}

\author{
ARTICLE HISTORY \\ Received : 2019-03-15 \\ Revised : 2021-05-27 \\ Accepted : 2019-06-15
}

\section{KEYWORDS}

\section{ICT}

Practicum Teachers

Classroom Context

Likert Scale

Importance Tools

\begin{abstract}
ICT is used in the classroom context helps pre-service teacher or practicum teachers to know more learning materials beyond the textbooks. This study aims at investigating perceptions using ICT in the learning process during their preservice teaching program. This survey research was taking EFL students at the English Education Department, Universitas Lancang Kuning, who conducted practice teaching or pre-service teaching at schools. Sixty-four students participated in this study. A set of questionnaires, with a Likert scale of 20 items and closed-ended five questions, was used to collect the data to ask their perception in ICT use during practice teaching at schools, the academic year 2019-2020. Some questionnaire items were adopted and developed from (Zareee 2011). The findings reveal that most pre-service teachers (90\%) used ICT in the classroom. The analysis using statistical analysis (SPSS ver. 20), it was found that the mean score at 4.08 with a standard deviation value at 0.144 categorized High level. The score of standard deviation means that all of the respondents' answers are the same agree or homogenous. It means that preservice teachers agree on the importance of using ICT in the classroom's learning process and acting as supportive tool to grasp meaningful English learning resources, especially in classroom settings.
\end{abstract}

\section{Introduction}

Information Communication and Technology (ICT), which is so rapid in this era of globalization, cannot again influence education. Global demands force the education world to always adjust technology with efforts to improve education. Teachers increase the use of the internet to help them prepare material used for learning in the classroom. The use of technology as a learning medium helps convey learning material, especially in English learning. ICT in school education is considered as one of the important tools to make education learner-centric and helps to reduce the digital divide between different socio-economic classes in a developing country like Indonesia.

Moreover, Practicum teachers ideally must have the ability and competence to use ICT for classroom learning. Equipping practice teachers with technological skills and knowledge is now considered a vital element of any teacher training program to train new teachers to meet the educational demands of the 21 st century. Therefore, it is important to establish whether these teachers apply these skills when they first arrive in the field and, otherwise, what could be the factors that hinder them (Tshepo and Abraham, 2017).
Also, this time almost all teacher training programs worldwide have a technology training component (Yuksel and Kavanoz, 2011). Therefore, compared to their predecessors, today's pre-service teachers are better positioned to make technology part of their teaching due to training. These new teachers do not have to unlearn the teaching habits that have been established for a long time. They could start with innovative teaching techniques that support the use of technology. This is why it is essential to focus on where new teachers begin their teaching to establish them towards revolutionary teaching.

Information and telecommunications have very important and real, especially since the community is currently heading towards the scientific community. ICT is a demand that prospective teachers must-have in the future. Teachers who can use ICT will greatly help in the learning process in the classroom because technology in principle is to facilitate someone in doing something. Now students are intense and familiar with the use of ICT, including the use of smartphones and PCs to find the references they need in learning English. The practicum teachers must update in obtaining and providing information so that his knowledge develops to the fullest. Students will be able to get something better 
and more accurate when they can get access to information through the internet. Teachers/ Practicum teachers also need more updates on ICT knowledge to make good teaching and create the best teaching for students. Because most students already use ICT a lot, smartphones, especially in their daily activities.

Therefore, based on the ideas mentioned above, the researcher will investigate Perceptions of English Education Department Students on ICT Use During Practice Teaching at Classroom Context with research questions as follow:

1. How are Perceptions of English Education Department Students on ICT Use During Practice Teaching at Classroom Context

Thus, this study attempts that perceptions on the use of ICT in the classroom context are high level it means good perceptions in learning and can be used as EFL learning strategies. This can be an effective supplementary material to make the learning process more interesting for students.

\section{Methods}

The study in this research is quantitative research. Creswell (2014) states that quantitative research is an approach for testing objective theories by examining the relationship between the variables. These variables, in turn, can be measured, typically on instruments, so that numbered data can be analyzed using statistical procedures.

This quantitative research was designed as a survey study. Survey research provides a quantitative or numeric description of trends, attitudes, or opinions of a population by studying that population sample. The researcher was use cross-sectional studies questionnaires for data collection with the intent of generalizing from a sample to a population. In this study, researchers used one variable, namely the Practicum Teachers Perceptions use of ICT in the Classroom in Teaching English. The instrument in this study was a questionnaire. Besides the essay questionnaire, the content is open-ended question practicum teacher used ICT in the classroom context. This questionnaire was distributed to the faculty of education and training of Universitas Lancang Kuning teachers, especially Practicum Teachers.

This research was conducted in May 2020 in the English Department (Practicum teachers) Faculty of Education and Teachers Training Universitas Lancang Kuning Academic Year 2019/2020. This campus is located at Yos Sudarso St. KM. 8, Rumbai, Pekanbaru, Riau. These research populations are the English Practicum Teachers in the English Department, Faculty of Education and Teachers Training in Universitas Lancang Kuning Academic Year 2019/2020. The sample consists of 64 students from practicum teachers' students in the seventh semester.

In order to collect the data, the researcher used an online questionnaire that was Google From. The questionnaire consisted of 25 items, such as an openended questionnaire using ICT at the classroom context, practicum teachers' knowledge about ICT, the Perception of ICT in the classroom, and Practicum Teachers Opinion Using ICT. Also, the researcher used the Likert scale for collecting the data. It means every item in the questionnaires consists of 5 choices, that is "Strongly Agree," "Agree", "Neutral", "Disagree", and "Strongly Disagree".

The data collected was analyzed using the SPSS statistical package. A descriptive statistics analysis was carried out to see the score of teachers' and students' answers.

After analyzing the data by using Descriptive Statistics, the researcher continued to analyzing it by categorize them into Katz and Kahn range Likert scale (1978) as follows:

\section{Findings and Discussion}

How are Perceptions of English Education Department Students on ICT Use During Practice Teaching at Classroom Context?

Before answer, the research design, the researcher gets answers from respondents on the use of media in classroom learning.

Table 1. Use ICT in the Classroom in Teaching and Learning Activities

\begin{tabular}{llrrrr}
\hline & & $\begin{array}{c}\text { Frequ } \\
\text { ency }\end{array}$ & $\begin{array}{c}\text { Perce } \\
\text { nt }\end{array}$ & $\begin{array}{c}\text { Valid } \\
\text { Percent }\end{array}$ & $\begin{array}{c}\text { Cumulative } \\
\text { Percent }\end{array}$ \\
\hline Valid & No & 6 & 9.4 & 9.4 & 9.4 \\
& Yes & 58 & 90.6 & 90.6 & 100.0 \\
& Total & 64 & 100.0 & 100.0 & \\
\hline
\end{tabular}

In this study, we can see table 1 . The researcher found that of 64 respondents $90.6 \%, 58$ students who used ICT in teaching in class, were used for learning media such as; Computers, Projectors, PowerPoint, Smartphones, Video, Audio, and Picture. And 9.4\% of $100 \%$ with a total of 6 students do not use ICT in classroom learning, they only use whiteboard and textbooks. 
Chart 1. Chart Percentage Practicum Teachers use ICT

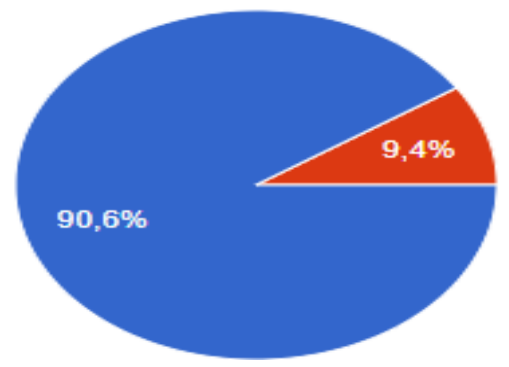

The chart percentage respondents use ICT, and blue

Classrooms Context, and red color 9,4\% practicum does color stated $90,6 \%$ practicum teachers use ICT in the not use ICT at Classroom Context.

Chart 2. Percentage Media Use ICT by Practicum Teachers

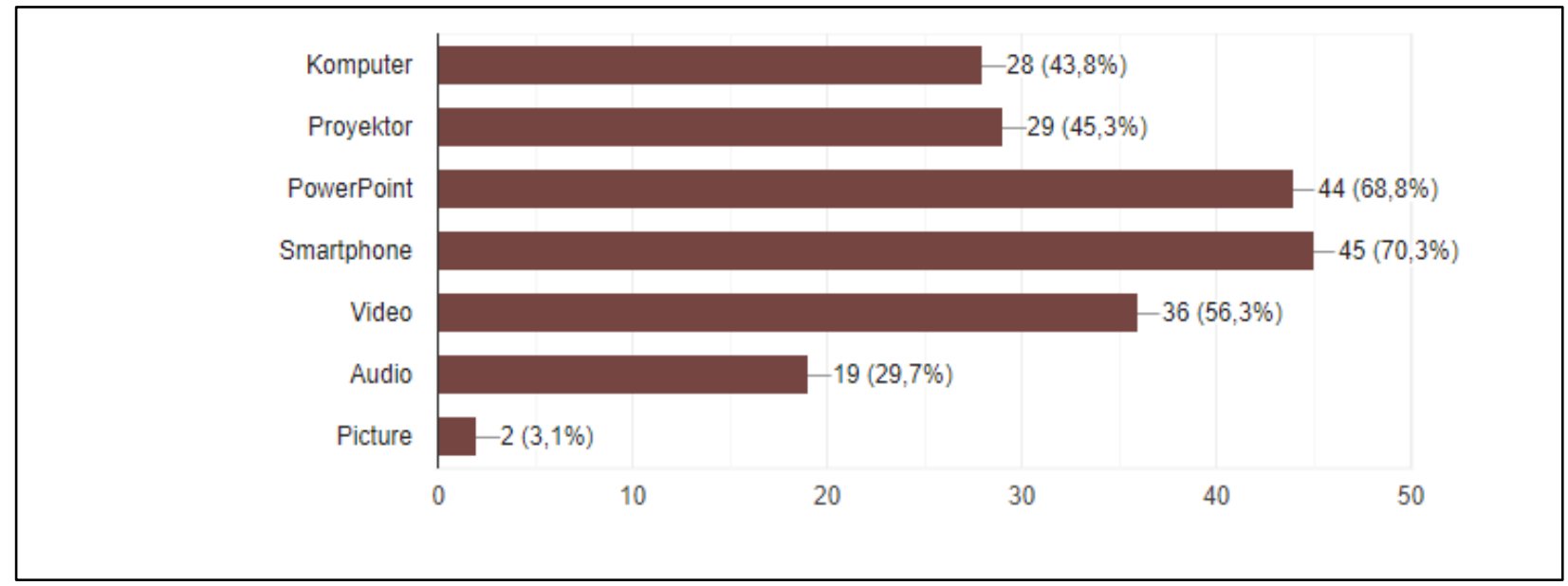

The media Information Communication and Technology (ICT) used by practicum teachers in teaching in the classroom context: From 64 respondents who used computers in learning activities as many as 28 respondents with a percentage value of $43.8 \%$.
Computer/laptop is one of the tools used by almost all teachers for educational purposes.In this indicator, ten questions were asked to the respondents of this research. To sum up the perceptions of ICT used in the classroom context by respondents (practicum teachers).

Table 2. ICT can be used to Create Learning Strategies for Teaching Materials Effectively.

\begin{tabular}{llrrrrr}
\hline & Frequency & Percent & \multicolumn{2}{c}{$\begin{array}{c}\text { Cumulative } \\
\text { Percent }\end{array}$} & Mean & Std. Dev \\
\hline Valid & SD & 2 & 3.1 & 3.1 & \\
\cline { 2 - 7 } $\mathrm{N}$ & 6 & 9.4 & 12.5 & \\
\cline { 2 - 7 } $\mathrm{A}$ & 30 & 46.9 & 59.4 & 4.22 & 0.863 \\
\hline SA & 26 & 40.6 & 100.0 & \\
\hline $\begin{array}{l}\text { Tot } \\
\text { al }\end{array}$ & 64 & 100.0 & & & \\
\hline
\end{tabular}

Table 2 indicated the statement is "ICT can be used to create learning strategies for teaching material effectively" 30 respondents choose "Agree" with a score percentage of $46 \%$. And then, the Respondents claims that ICT is very useful to use in learning strategies in the classroom context. But, the researcher 
found $3 \%$ of respondents choose the negative answer "Strongly Disagree". For standard deviation is 0.863 . The score of standard deviation means that all of the answers from respondents are same or homogenous. In addition, for average of practicum teachers score is 4.22 , it means this statement claims ICT can be used to create learning strategies for teaching material effectively at class EFL cotegorized High.

Table 3. ICT can Spread Knowledge and Information Faster than Traditional Method

\begin{tabular}{|c|c|c|c|c|c|c|}
\hline & & Frequency & Percent & $\begin{array}{c}\text { Cumulative } \\
\text { Percent }\end{array}$ & Mean & Std. Dev \\
\hline \multirow[t]{5}{*}{ Valid } & SD & 2 & 3.1 & 3.1 & & \\
\hline & $\mathrm{N}$ & 6 & 9.4 & 12.5 & & \\
\hline & A & 27 & 42.2 & 54.7 & 4.27 & 0.877 \\
\hline & $\mathrm{SA}$ & 29 & 45.3 & 100.0 & & \\
\hline & Total & 64 & 100.0 & & & \\
\hline
\end{tabular}

Table 3 shows, From 64 respondents, 45\% choose "Strongly Agree" in a statement "ICT can spread knowledge and information faster than traditional methods, " and $42 \%$ of respondents also choose positive answers "Agree" that ICT can spread knowledge and information faster. But, two respondents negative answer "Strongly Disagree" with scale 3\%. This is a low score from the respondent answer than a positive answer. For standard deviation is 0.877. The score of

Table 4.

Facilitate

Teachers for Assessment standard deviation means that all of the answers from respondents are the same or homogenous. Also, for an average of practicum teachers score is 4.27, ICT is spread knowledge and information faster than traditional categorized High.

\begin{tabular}{llccc}
\cline { 2 - 4 } A & 32 & 50.0 & 73.4 \\
\cline { 2 - 4 } SA & 17 & 26.6 & 100.0 \\
\cline { 2 - 4 } Total & 64 & 100.0 & \\
\hline
\end{tabular}

Table 4 shows, 32 respondents choose "Agree" with a scale $50 \%$ in a statement "ICT can facilitate practicum teachers for student assessment". Respondents using ICT to calculate score students because to save time and be more accurate than manual calculation. And then, 26\% of respondents choose "Strongly Agree" because score positive answer more than negative answer score only 1,6\% "Strongly Disagree" and "Disagree”. For standard deviation is 0.924 . The score of standard deviation means that all of the answers from respondents are the same or homogenous. In addition, for an average of practicum teachers score is 4.19 , it means that ICT's can facilitate practicum teachers for student assessment is categorized into High. 
Table 5. ICT (Referring to Computers, Videos, Hardware, Software, and Networks) is Beneficial to Add my Knowledge and Skills to Practicum Teachers

\begin{tabular}{|c|c|c|c|c|c|c|}
\hline & & Frequency & Percent & $\begin{array}{c}\text { Cumulative } \\
\text { Percent }\end{array}$ & Mean & $\begin{array}{l}\text { Std. } \\
\text { Dev }\end{array}$ \\
\hline \multirow[t]{5}{*}{ Valid } & SD & 2 & 3.1 & 3.1 & & \\
\hline & $\mathrm{N}$ & 9 & 14.1 & 17.2 & & \\
\hline & $\mathrm{A}$ & 28 & 43.8 & 60.9 & 4.16 & 0.895 \\
\hline & SA & 25 & 39.1 & 100.0 & & \\
\hline & Total & 64 & 100.0 & & & \\
\hline
\end{tabular}

standard deviation is 0.895. The statement is

"ICT add my knowledge and skills as a practicum teacher" 28 respondents choose "Agree" with a percentage of $43 \%$. Using ICT referring to a computer, video, hardware, software, and network have benefits to add respondents knowledge and skills as practicum teachers in the classroom context. Because only $3 \%$ choose the negative answer "Strongly Dissagree", the researcher found a positive answer is a high score. For score of standard deviation means that all of the answers from respondents are the same or homogenous. In addition, for an average of practicum teachers score is 4.16 , it means that using ICT is beneficial to add participant knowledge and skills as a practicum teacher is categorized into High. So, using ICT is beneficial to add participant knowledge and skills as practicum teachers.

Table 6. In Classroom Context, ICT is a More Powerful Tool than Discussion in the Classroom Without using ICT

\begin{tabular}{|c|c|c|c|c|c|c|}
\hline & & Frequency & Percent & $\begin{array}{c}\text { Cumulative } \\
\text { Percent }\end{array}$ & Mean & $\begin{array}{l}\text { Std. } \\
\text { Dev }\end{array}$ \\
\hline \multirow[t]{6}{*}{ Valid } & SD & 1 & 1.6 & 1.6 & & \\
\hline & $\mathrm{D}$ & 2 & 3.1 & 4.7 & & \\
\hline & $\mathrm{N}$ & 16 & 25.0 & 29.7 & 3.94 & 0.906 \\
\hline & A & 26 & 40.6 & 70.3 & & \\
\hline & SA & 19 & 29.7 & 100.0 & & \\
\hline & Total & 64 & 100.0 & & & \\
\hline
\end{tabular}

Table 6 shows, from 64 respondents, $40 \%$ choose "Agree" with the statement is "ICT is a more powerful tool than discussion in the classroom without using ICT". Positive answer score higher than negative answer only 1\% "Strongly Disagree" and 3\% "Disagree". The researcher claim discusses learning the material more effectively uses ICT than traditional tools. Using ICT discussion can be everywhere, not only in a classroom context. For standard deviation is 0.906.
The score of standard deviation means that all of the answers from respondents are the same or homogenous. In addition, for an average of practicum teachers score is 3.94, it means that ICT is a more powerful tool than discussion in the classroom without using ICT is categorized into Moderate. So, "ICT is a more powerful tool than discussion in the classroom without using $I C T$ " is successful to used ICT in the classroom context as learning media. 
Table 7. ICT can be used as a Sophisticated Teaching Tool in the Classroon

\begin{tabular}{|c|c|c|c|c|c|c|}
\hline & & Frequency & Percent & $\begin{array}{l}\text { Cumulative } \\
\text { Percent }\end{array}$ & Mean & $\begin{array}{l}\text { Std. } \\
\text { Dev }\end{array}$ \\
\hline \multirow[t]{5}{*}{ Valid } & $\mathrm{SD}$ & 2 & 3.1 & 3.1 & & \\
\hline & $\mathrm{N}$ & 13 & 20.3 & 23.4 & & \\
\hline & A & 21 & 32.8 & 56.2 & 4.14 & 0.957 \\
\hline & SA & 28 & 43.8 & 100.0 & & \\
\hline & Total & 64 & 100.0 & & & \\
\hline
\end{tabular}

$\mathrm{f}$

Table 7 shows, the researcher asked the question "ICT can be used as a sophisticated teaching tool in the classroom" for 64 respondents $43 \%$ answer "Strongly Agree," and 32\% respond "Agree". While 3\% of respondents choose the negative answer "Strongly Disagree". The researcher gets a high score positive answer. ICT can be used as a sophisticated teaching tool in the classroom, and respondents assume that using ICT can make teaching and learning more modern. Teaching and learning used ICT, and it is an attempt to involve and use professional knowledge possessed by teachers to achieve curriculum goals. For standard deviation is 0.957 . The score of standard deviation means that all of the answers from respondents are the same or homogenous. In addition, for an average of practicum teachers score is 4.14 , it means that ICT is tools sophisticated to support learning English foreign language in a classroom context is categorized into High. So, ICT is tools sophisticated to support learning English foreign language in a classroom context

Table 8. ICT is More Effective for Teaching and Learning in Class than Books and Other Printed Materials

\begin{tabular}{|c|c|c|c|c|c|c|}
\hline & & Frequency & Percent & $\begin{array}{c}\text { Cumulative } \\
\text { Percent }\end{array}$ & Mean & $\begin{array}{l}\text { Std. } \\
\text { Dev }\end{array}$ \\
\hline \multirow[t]{5}{*}{ Valid } & $\mathrm{SD}$ & 2 & 3.1 & 3.1 & & \\
\hline & $\mathrm{N}$ & 19 & 29.7 & 32.8 & & \\
\hline & $\mathrm{A}$ & 26 & 40.6 & 73.4 & 3.88 & 0.917 \\
\hline & SA & 17 & 26.6 & 100.0 & & \\
\hline & $\begin{array}{l}\text { Tota } \\
1\end{array}$ & 64 & 100.0 & & & \\
\hline
\end{tabular}

Table 8 shows, with the statement, is "ICT is more effective for teaching and learning in class than books and other printed materials". The researcher found 43 respondents choose the positive answer with scale $40 \%$ "Agree" and 26\% "Strongly Agree". Like using video or audio is more effective so that make to motivate the student to get additional material which is not in the book. From 64 respondents, 3\% answer "Strongly Disagree" because in school not using ICT as a media to support students' motivation or nothing facility ICT in that school. For standard deviation is 0.917. The score of standard deviation means that all of the answers from respondents are same or homogenous. In addition, for average of practicum teachers score is 3.88 , ICT is more effective for teaching and learning in class than books and other printed materials is categorized into Moderate. So, perceptions of ICT use are more effective for teaching and learning in class than books and other printed materials. 
Table 9. ICT Gives Important Contributions for Human Society in General

\begin{tabular}{llrrrrr}
\hline & & \multicolumn{3}{c}{$\begin{array}{c}\text { Cumulative } \\
\text { Percent }\end{array}$} & Mean & $\begin{array}{c}\text { Std. } \\
\text { Dev }\end{array}$ \\
\hline Valid & SD & 2 & 3.1 & 3.1 & \\
\cline { 2 - 7 } & $\mathrm{N}$ & 9 & 14.1 & 17.2 & & \\
\cline { 2 - 7 } $\mathrm{A}$ & 31 & 48.4 & 65.6 & 4.11 & 0.875 \\
\hline $\mathrm{SA}$ & 22 & 34.4 & 100.0 & & \\
\hline Total & 64 & 100.0 & & & \\
\hline
\end{tabular}

From table 9, the statement is "ICT gives important contributions for human society in general". 31 respondents choose "Agree" to answer the question, like parents of students, can get information faster about the new rules in school. And then, 34\% respond than "Strongly Agree" with ICT give an important contribution to human society. While a negative answer "Strongly Disagree" has 3\%. For standard deviation is

Table 10.

Educational

Values in
Classroom

\begin{tabular}{|c|c|c|c|c|c|c|}
\hline & & Frequency & Percent & $\begin{array}{c}\text { Cumulative } \\
\text { Percent }\end{array}$ & Mean & $\begin{array}{l}\text { Std. } \\
\text { Dev }\end{array}$ \\
\hline \multirow[t]{5}{*}{ Valid } & $\mathrm{SD}$ & 2 & 3.1 & 3.1 & & \\
\hline & $\mathrm{N}$ & 20 & 31.2 & 34.4 & & \\
\hline & A & 25 & 39.1 & 73.4 & 3.86 & 0.924 \\
\hline & $\mathrm{SA}$ & 17 & 26.6 & 100.0 & & \\
\hline & Total & 64 & 100.0 & & & \\
\hline
\end{tabular}

0.875. The score of standard deviation means that all of the answers from respondents are the same or homogenous. In addition, for average of practicum teachers score is 4.11 , it means that ICT gives important contributions to human society, in general, is categorized into High. So, ICT gives important contributions to human society in general.
ICT Offer or Teaching the Context
Table 10 shows, this research, the researcher found 42 respondents choose the positive answer with scale $39 \%$ "Agree" and 26\% "Strongly Agree" from statement "ICT offer educational / teaching values in classroom context". This is a high score that responds that ICT has positive values in teaching and learning at school. Besides, 20 respondents choose a "Neutral" answer with a scale of $31 \%$ and the negative answer "Strongly
Disagree" has 3\%. Respondents claim that using ICT in learning has a positive impact on students. For standard deviation is 0.924 . The score of standard deviation means that all of the answers from respondents are same or homogenous. In addition, for average of practicum teachers score is 3.86 , it means that ICT is offer for educational / teaching values is categorized into Moderate. So, ICT is offer for educational / teaching values in the classroom context. 
Table 11. ICT Tools can Facilitate Practicum Teachers to do Assessment for Students

\begin{tabular}{|c|c|c|c|c|c|c|}
\hline & & Frequency & Percent & $\begin{array}{c}\text { Cumulative } \\
\text { Percent }\end{array}$ & Mean & $\begin{array}{l}\text { Std. } \\
\text { Dev }\end{array}$ \\
\hline \multirow[t]{5}{*}{ Valid } & SD & 2 & 3.1 & 3.1 & & \\
\hline & $\mathrm{N}$ & 12 & 18.8 & 21.9 & & \\
\hline & A & 29 & 45.3 & 67.2 & 4.05 & 0.898 \\
\hline & SA & 21 & 32.8 & 100.0 & & \\
\hline & Total & 64 & 100.0 & & & \\
\hline
\end{tabular}

Table 11 shows, 29 respondents choose "Agree" Disagree". For standard deviation is 0.898 . The score of with the scale $45 \%$ in the statement "ICT tools can facilitate practicum teachers to assess students". Respondents using ICT to calculate score students because to save time and be more accurate than manual calculation. And then, $32 \%$ respondents choose "Strongly Agree" because score positive answer more than negative answer score only 3\% " Strongly standard deviation means that all of the answers from respondents are same or homogenous. In addition, for average of practicum teachers score is 4.05 , it means that ICT can facilitate practicum teachers to do assessments for students is categorized into High. So, use ICT can facilitate practicum teachers to do assessments for students.

Table 12. (Mean Table)

Perceptions Practicum Teachers use ICT at Classroom Context

\begin{tabular}{|c|c|c|c|c|}
\hline $\begin{array}{l}\text { Number of } \\
\text { Question }\end{array}$ & Statements & $\mathbf{N}$ & $\mathbf{M}$ & $\begin{array}{l}\text { GRAN } \\
\text { D } \\
\text { MEAN }\end{array}$ \\
\hline Q2 & $\begin{array}{l}\text { As far as I know, ICT can be used to } \\
\text { create learning strategies for teaching } \\
\text { materials effectively }\end{array}$ & & 4.22 & \\
\hline Q3 & $\begin{array}{l}\text { I know that ICT can spread knowledge } \\
\text { and information faster than traditional } \\
\text { methods }\end{array}$ & & 4.27 & \\
\hline Q4 & $\begin{array}{l}\text { I know that ICT can facilitate practicum } \\
\text { teachers for student assessment }\end{array}$ & & 4.19 & \\
\hline Q9 & $\begin{array}{l}\text { ICT (referring to computers, videos, } \\
\text { hardware, software, and networks) is } \\
\text { beneficial to add my knowledge and } \\
\text { skills as a practicum teachers }\end{array}$ & & 4.16 & \\
\hline Q10 & $\begin{array}{l}\text { In Classroom Context, ICT is a more } \\
\text { powerful tool than discussion in the } \\
\text { classroom without using ICT }\end{array}$ & 64 & 3.94 & 4.08 \\
\hline Q11 & $\begin{array}{l}\text { ICT can be used as a sophisticated } \\
\text { teaching tool in the classroom. }\end{array}$ & & 4.14 & \\
\hline Q12 & $\begin{array}{l}\text { In my view, ICT is more effective for } \\
\text { teaching and learning in class than } \\
\text { books and other printed materials }\end{array}$ & & 3.88 & \\
\hline Q13 & I think ICT gives important & & 4.11 & \\
\hline
\end{tabular}




\begin{tabular}{lll}
\hline Q14 & $\begin{array}{l}\text { contributions for human society in } \\
\text { general. }\end{array}$ & $\begin{array}{l}\text { I think ICT offer educational / teaching } \\
\text { values in classroom context. }\end{array}$ \\
\hline $\mathbf{Q 1 5}$ & $\begin{array}{l}\text { I know that ICT tools can facilitate } \\
\text { practicum teachers to do assessment for } \\
\text { students. }\end{array}$
\end{tabular}

Table 12 shows, the mean of questionnaire about the practicum perceptions use ICT in the classroom context. From 64 respondents researcher found that "I know that ICT can spread knowledge and information faster than traditional methods" have "higher mean" score (4.27) in number of question Q3. The use ICT in learning process can spread knowledge and information faster. From this statement, the teacher can provide information to students quickly. Also, students will get information learning material quickly from the teachers. Besides, statements that have a mean $<4.00$ this is "low mean" namely "I think ICT offer educational/teaching values in classroom context" with mean score (3.86) Q14. In addition, the researcher used SPSS 16 to analyze the data to get the scores of descriptive statistics. The scores of it can be seen as follow:

\begin{tabular}{|c|c|}
\hline $\begin{array}{l}\text { Sum } \\
\text { Mode } \\
\text { Median } \\
\text { Mean } \\
\text { Variance } \\
\text { Standard Deviation } \\
\text { Range }\end{array}$ & $\begin{array}{l}: 40.82 \\
: 3.86 \\
: 4.12 \\
: 4.08 \\
: .021 \\
: 0.144 \\
=\text { Minimum: } 3.86 \\
=\text { Maximum: } 4.27\end{array}$ \\
\hline
\end{tabular}

Based on the result of descriptive statistics above, it can be seen that generally, the perceptions of English education department students on ICT use during practice teaching at classroom context in term of learning models is categorized into high level. In addition, the table above shows that the total of practicum teacher scores of using ICT at classroom context 40.82, mode of practicum teachers score is 3.86 , the median of practicum teachers score 4.12, the variance of students' score is .021, and for standard deviation is 0.144 . The score of standard deviation means that all of the answers from respondents are same or homogenous. In addition, for an average of practicum teachers score is 4.08 , it means that practicum teachers' perceptions of using ICT in a classroom context is categorized into High. Therefore, it can be said that most of the students, had answered all of the items in ranges of agree up to strongly disagree.

\section{Conclusion and Suggestions}

Based on this study's results about the practicum teachers' perception of using ICT in EFL classrooms, some conclusions can be drawn. The findings reveal that most practicum teachers (90\%) used ICT in the classroom. On using statistical analysis (SPSS), it was found that the mean score at 4.08 with a standard deviation value at 0.144 categorized High level. The score of standard deviation means that all of the answers from respondents are the same agree or homogenous it means that practicum teachers agree on the importance of using ICT in the learning process in the classroom. In addition, the use of ICT has benefits for practicum teachers. Therefore, the researcher concludes that it is a supportive tool to grasp meaningful English learning resources, especially in classroom settings. To conclude, this present study was administered to find out Practicum teachers perceptions' towards the benefits use of ICT in the English language learning process.

This research shows that perceptions on the use of ICT in the classroom context is high level. It means good perceptions in learning and can be used as EFL learning strategies. The use of ICT is recommended to be applied to practicum teachers/teachers in teaching EFL. Teachers should learn more about ICT and apply it to their teaching to improve their knowledge and skills in teaching EFL. This can be an effective supplementary material to make the learning process more interesting for students.

\section{References}


Abuhmaid, A. (2013). Information and communication technology integration within the practicum. Science journal of education, 1(5), 51-59.

Al-Munawwarah, S. F. (2014). Teachers' Perceptions on The Use of ICT In Indonesian EFL Learning Context. English Review: Journal of English Education, 3(1), 70-80.

Arikunto, S., (2010). Prosedur penelitian: Suatu Pendekatan Praktik. (Edisi Revisi). PT. Rineka Cipta. Jakarta.

Arikunto, S., (2011). Prosedur Penelitian: Suatu Pendekatan Praktik. Edisi Revisi VII. PT. Rineka Cipta. Jakarta.

Singhavi, C., \& Basargekar, P. (2019). Barriers Perceived by Teachers for Use of Information and Communication Technology (ICT) in the Classroom in Maharashtra, India. International Journal of Education and Development using Information and Communication Technology, $15(2), 62-78$

Creswell, J. W. (2014). Research Design: Qualitative, Quantitative, and Mixed Method Approaches (p. 285). Thousand Oaks, CA.

Hismanoglu, M. (2012). Prospective EFL teachers' perceptions of ICT integration: A study of distance higher education in Turkey. Educational Technology \& Society, 15(1), 185-196.

Goodwin, A. L., Low, E., Ng, P., Yeung, A. S., \& Cai, L. (2015). Enhancing playful teachers' perception of the importance of ICT use in the classroom: The role of risk taking as a mediator. Australian Journal of Teacher Education, 40(4), 132-150.

Granito, M., \& Chernobilsky, E. (2012). The effect of technology on a student's motivation and knowledge retention. Proceedings of Northeastern Educational Research Association Conference (NERA).

Juliana, R. and Muslem, A. (2017) The Use Of Information And Communication Technology (Ict) Amongst Efl Teachers: Perceptions And Challenges. English Education Journal (EEJ), 8(4), 469-487, October 2017

Karakaya, K. (2010). An investigation of English language teachers' attitudes toward computer technology and their use of technology in language teaching Ankara, Turkey. (Unpublished Master's thesis). Middle East Technical University,. Retrieved June 22, 2015.

Katz, D., \& Kahn, R. L. (1978). The social psychology of organizations (Vol. 2, p.528). New York: Wiley.
Kolbakova, F. (2014). The use of ICT among the teachers of English in Estonia by comparison with Europe and Asia: Tartu, Estonia (Unpublished Master's thesis, University of Tartu).

Liu, S. (2012). A multivariate model of factors influencing technology use by pre-service teachers during practice teaching. Educational Technology \& Society. Educational Technology \& Society, 15(4), 137-149.

Murley, L. D., Jukes, P., \& Stobaugh, R. (2013). "Raising expectations for pre-service teacher use of technology".,International Journal of Humanities and Social Science.

Muslem, A., Yusuf, Y. Q., \& Juliana, R. (2018). Perceptions and barriers to ICT use among English teachers in Indonesia. Teaching English with Technology, 18(1), 3-23.

Permendiknas No. 35 of 2010 concerning "Technical Instructions for Teachers' Position and Functions and their Credit figures". Retrieved from: https://peraturan.bpk.go.id/Home/Details/163916/p ermendikbud-no-35-tahun-2010

Permendiknas No.74 of 2008 concerning " Teachers that there are several main tasks of a teachers". Retrieved from: https://peraturan.bpk.go.id/Home/Details/4892/ppno-74-tahun-2008

Rabah, J. (2015). Benefits and challenges of Information and Communication Technologies (ICT) integration in Québec English schools. TOJET: The Turkish Online Journal of Educational Technology, 14(2), 24-31.

Rank, T., Warren, C., \& Millum, T. (2011). Teaching English using ICT: A Practical Guide for Secondary School Teachers. London: Continuum.

Shaikh, BK. and Alagannawar, A. (2018) Active Learning Strategies In Classroom Using Ict Tool . Aarhat Multidisciplinary International Education Research Journal (AMIERJ), 6, 89-95.

Sharma, S. (2019). Descriptive Statistics. Paris: Horizons University.

Sudijono, Anas. 2012. Pengantar Statistik Pendidikan, Jakarta: PT. Raja Grafindo

Sugiyono. 2015. Statistika untuk penelitian. Bandung: Alvabeta.

The 1945 Constitution of the Republic of Indonesia of 2005 Chapter I Number 157 clause 9. "Qualifications for Educators": retrieved from: https://www.mkri.id/public/content/infoumum/reg ulation/pdf/UUD45\%20ASLI.pdf 
Tshepo,B., \& Abraham,N., (2017) Technology use by pre-service teachers during teaching practice: Are new teachers embracing technology right away in their first teaching experience?. Australasian Journal of Educational Technology, 2017, 33(1). 48-61

Valk, J. H., Rashid, A. T., \& Elder, L. (2010). Using mobile phones to improve educational outcomes: An analysis of evidence from Asia. The International Review of Research in Open and Distance Learning, 11(1), 117-140.

Wekke, I. S., \& Hamid, S. (2013). Technology on language teaching and learning: A research on Indonesian Pesantren. Procedia-Social and Behavioral Sciences, 83, 585-589.

Zare-ee, A. (2011). University Teachers' Views on the Use of Information Communication Technologies in Teaching and Research. Turkish Online Journal of Educational Technology-TOJET, 10(3), 318327. 